\title{
Decoding Alzheimer's in the age of genome-wide analyses
}

\section{Citation}

Tanzi, Rudolph E. 2013. “Decoding Alzheimer's in the age of genome-wide analyses." Molecular Neurodegeneration 8 (Suppl 1): 01. doi:10.1186/1750-1326-8-S1-01. http:// dx.doi.org/10.1186/1750-1326-8-S1-01.

\section{Published Version}

doi:10.1186/1750-1326-8-S1-01

\section{Permanent link}

http://nrs.harvard.edu/urn-3:HUL.InstRepos:11879442

\section{Terms of Use}

This article was downloaded from Harvard University's DASH repository, and is made available under the terms and conditions applicable to Other Posted Material, as set forth at http:// nrs.harvard.edu/urn-3:HUL.InstRepos:dash.current.terms-of-use\#LAA

\section{Share Your Story}

The Harvard community has made this article openly available.

Please share how this access benefits you. Submit a story.

Accessibility 


\title{
Decoding Alzheimer's in the age of genome-wide analyses
}

\author{
Rudolph E Tanzi \\ From Molecular Neurodegeneration: Basic biology and disease pathways \\ Cannes, France. 10-12 September 2013
}

\begin{abstract}
Alzheimer's disease (AD) is strongly influenced by genetic factors as evidenced by numerous family and twin studies. Over the past two decades, others and we have co-discovered three early-onset familial AD genes, APP, PSEN1, and PSEN2, which can carry any of $>200$ fully penetrant mutations characterized by mendelian inheritance. For late-onset $\mathrm{AD}$, the most prevalent and highest impact risk factor is the epsilon 4 variant of $A P O E$, which increases risk by 3.7 -fold in the heterozygous state and $>10$-fold when two copies are inherited. As part of our Alzheimer's Genome Project funded by the Cure Alzheimer's Fund and the NIMH, we have been identifying novel AD candidate genes. In Bertram et al. (2008), we reported genome-wide association of AD with several loci including the spinocerebellar ataxia 1 gene, ATXN1, and the SIGLEC3 gene, CD33. Functional studies of the ATXN1 gene carried out both in vitro and in vivo in ATXN1 knockout mice show that ATXN1 can regulate $A \beta$ levels via modulation of $\beta$-secretase. $C D 33$ is just one of several genes (TREM2, CR1, etc) involved in the innate immune system of the brain that have been associated with AD risk. In addition, we discovered association of AD with $A D A M 10$, which encodes the major $\alpha$-secretase in the brain. Re-sequencing of this gene in the best associated $\mathrm{AD}$ families led to two rare mutations that tightly co-segregated with AD in seven (of 1000) AD families screened, all with average age of onset $\sim 70$ years. We have shown both mutations to impair ADAM10 nonamyloidogenic cleavage of APP in vitro and in transgenic mice, including double trangenics with AD (tg2576) mice. Thus, these are the first rare, highly penetrant mutations reported for late-onset $\mathrm{AD}$. We have also carried out genome-wide association studies on $>800$ well-characterized late-onset AD families (NIMH and NIA-LOAD samples) using Affymetrix genotyping arrays containing either one
\end{abstract}

Massachusetts General Hospital/Harvard Medical School, Charlestown, MA, USA

(C) 2013 Tanzi; licensee BioMed Central Ltd. This is an Open Access article distributed under the terms of the Creative Commons Attribution License (http://creativecommons.org/licenses/by/2.0), which permits unrestricted use, distribution, and reproduction in any medium, provided the original work is properly cited. million (6.0) or 20,000 coding SNPs. More recently, we have performed whole genome sequencing (Illumina, Hiseq) on over 1500 samples from AD families/sibships. The elucidation of the genes and functional variants influencing risk for AD should continue to enhance our understanding of AD etiology and pathogenesis. Ultimately, these genes will be used to predict risk for $\mathrm{AD}$ and guide novel the development of therapies for the effective treatment and prevention of this terrible disease.

Published: 13 September 2013

doi:10.1186/1750-1326-8-S1-O1

Cite this article as: Tanzi: Decoding Alzheimer's in the age of

genome-wide analyses. Molecular Neurodegeneration 2013 8(Suppl 1):01.

Submit your next manuscript to BioMed Central and take full advantage of:

- Convenient online submission

- Thorough peer review

- No space constraints or color figure charges

- Immediate publication on acceptance

- Inclusion in PubMed, CAS, Scopus and Google Scholar

- Research which is freely available for redistribution
C Biomed Central 